Annals of Warsaw University of Life Sciences - SGGW

Land Reclamation No 46 (4), 2014: 267-278

(Ann. Warsaw Univ. Life Sci. - SGGW, Land Reclam. 46 (4), 2014)

\title{
Terrestrial Laser Scanning (TLS) as a detection method of the natural river valley microtopography - case study of the Upper Biebrza
}

\author{
MARCIN BRACH ${ }^{1,2}$, JAROSŁAW CHORMAŃSKI ${ }^{1}$ \\ ${ }^{1}$ Department of Hydraulic Engineering, ${ }^{2}$ Computer Centre \\ Warsaw University of Life Sciences - SGGW
}

\begin{abstract}
Terrestrial Laser Scanning (TLS) as a detection method of the natural river valley microtopography - case study of the Upper Biebrza. This paper concerns the use of Terrestrial Laser Scanning (TLS) methods and the Geographic Information Systems (GIS) analysis to determine microtopography of a natural river valley, case study of the upper Biebrza valley. The scientific problem analyzed in this paper is a morphology of the selected segments of the valley covered by sedge ecosystems which in natural stage form a characteristic tussocks from their root systems. In order to capture the microtopography it was necessary to remove vegetation from the selected areas, and then, for a five typical location, registration of its structure using the laser scanner. As a result the point cloud was generated for each of the selected area and after GIS analysis the microtopography was obtained in form of digital terrain model (DTM). The DTM of each area represents valleys microstructure possible to obtain by use of TLS (TLS DTM), is usually not registered by the Airborne Laser Scanning (ALS), and is the main reason of inaccuracy of the DTM obtained based on ALS. The resulting TLS DTM has been processed by various filtering methods to lower the noise and fill the voids from blocking the laser beam by a tussocks. Finally, this allowed to determine the spatial structure of each measurement field.
\end{abstract}

Key words: Terrestrial Laser Scanning, upper Biebrza basin, Geographic Information Systems, sedges, river valley microtopography

\section{INTRODUCTION}

Natural river valleys are often used as polders - a temporarily water storage reservoirs during the flood. This direction of flood protection is important due to the fact that it is more effective, much cheaper and environmental friendly comparing to technical construction of flood defense embankments (Jankowski, 2003). A reliable determination of the amount of water that can be stored by the valley depends on the correct determination of its landform. Therefore, the acquisition of high quality Digital Terrain Model (DTM) is a necessary condition. Airborne Laser Scanning (ALS) technology is increasingly being used as a method for the DTM determination. The IT System of the Country's Protection against extreme hazards (ISOK) of Poland is nearing its completion, carried out by the National Water Management Authority - KZGW (http://www.isok. gov.pl/en). As a part of this system the maps of flood threat will be determined for the majority of Polish rivers using the DTM based on the data acquired by the 
ALS. However, in case of natural river valleys, protected areas in the form of national parks and areas included to the Natura 2000 network, the DTM accuracy falls significantly, overestimating the area elevation in average of $0.3-0.5 \mathrm{~m}$ (unpublished experience of the authors). This applies particularly to natural vegetation formed in the non-managed valleys, like reeds and especially several types of sedges, which in periodically flooded areas build tussocks from their root systems in order to survive (Opdekamp et al., 2012). Microtopography created by those sedges can be an important factor of the valleys. Influence of these phenomena on hydrological processes like water storage or for calculation of the friction coefficient in hydrodynamic models was never analyzed before. Works so far in the field of hydrodynamic modelling of flood in natural river valleys covered mostly by dense vegetation included the calculation of flood extent and duration of flood based on DTM (Mirosław-Świątek et al., 2004, et al., 2007, et al. 2008, Chormański et al., 2009, Okruszko et al., 2010), and the issue of verification of hydrodynamic models using remote sensing methods (Mirosław-Świątek and Chormański, 2007, Chormański et al., 2011a). Recently, Terrestrial Laser Scanning (TLS) became very popular in many fields of science, inter alia natural science. It is used in forestry to estimate forest variables (Moskal and Zheng, 2012) or forest stands (Wężyk, 2009), it also found usage in river valleys to determine friction coefficient of small trees and bushes in the valley (Kałuża and Strzeliński, 2009). The TLS application can be limited in dense vegetation, however recently methods arise to eliminate vegetation reflections from point clouds (Fan et al., 2014). This technology has its application in acquiring and modelling landform data. It can be used in monitoring of changing forms due to geomorphic processes, like in river valley in Polar environment (Kociuba et al., 2014a, Kociuba, 2014) or coastal cliffs (Kuhn and Prüfer, 2014) or to assess the dynamics of development of forested loess gullies (Kociuba et al., 2014b). TLS can also be combined with ALS, like Bremer and Sass (2012) used this combination to quantify erosion and deposition of limestone debris after heavy rainstorm. Another application of TLS data for acquiring terrain topography is proposed by Bubeck et al. (2014). They combined TLS data with ground penetrating radar (GPR) to document tectonic geomorphology of bedrock scarps.

Method proposed in this paper serves to correctly determine the river valley microtopography which can be used in further analysis as a base for acquiring accurate DTM of a natural river valley. As a part of field measurements registration of tussocks on selected fields was made using TLS technology, on which basis the DTM of each field was determined. As a result, an analysis of each fields the DTM accuracy and quality was processed. 


\section{STUDY AREA}

Biebrza river was selected for the research area due to natural type of the valley. The whole valley is protected by Biebrza National Park. The measurements were done on selected locations in the upper Biebrza river basin (Fig. 1). In this part, the valley is relatively narrow comparing to other basins (from a few hundred meters up to $1.5 \mathrm{~km}$ wide),
Measurement fields were located in the representative locations in eastern part of the valley. Four fields near Rogożyn Nowy (marked with symbols from R1 to R4) and one field (marked as R5) near Szuszalewo. Most of the fields were agricultural extensive areas, except the field R1 on which was mowed in recent years (thereby tussocks on this fields were only in development stage).

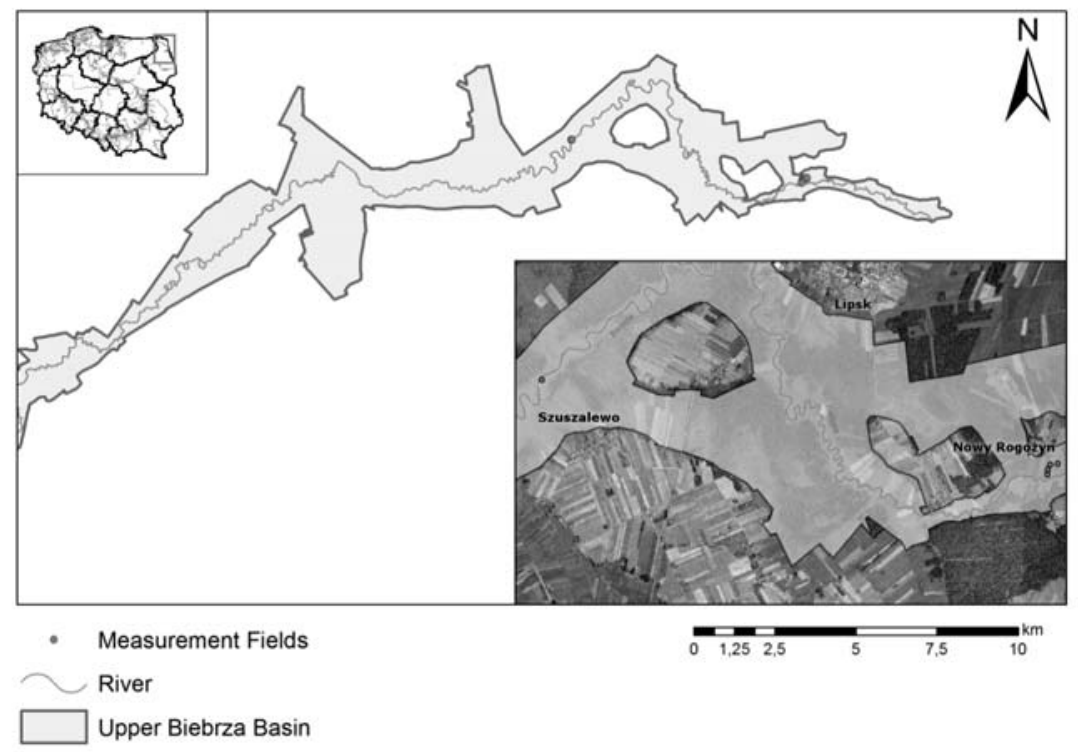

FIGURE 1. Measurement fields location

covered by a natural vegetation or extensively used for agriculture (Chormański et al., 2011b). The valley is in dominated amount supplied by groundwater, which is particularly high close to the plateau (Anibas et al., 2012), causing by local inundation. Flooding have a big factor on the valleys water supply during spring, which remains for a few weeks.

\section{MATERIAL AND METHODS}

\section{Preparing of fields and measurement using Terrestrial Laser Scanning (TLS)}

TLS measurements were done by use of the FARO Focus 3D phase-shift laser scanner. The scanner is equipped in an infrared laser, with a $905 \mathrm{~nm}$ wavelength. Scanning distance accuracy is up to $\pm 2 \mathrm{~mm}$. Scanning was performed 
on five measurement fields with an area about $25 \mathrm{~m}^{2}(5 \times 5 \mathrm{~m})$. Each field was covered by sedge vegetation, which was cut to prepare, tussocks for scanning. The greens cutting was performed up to 4 days before scanning. It was made in order to allow to capture their shape and height by the laser beam of scanner. Scanning resolution was set to $8 \mathrm{~mm}$ per $10 \mathrm{~m}$ for fields R2-R5 and $15 \mathrm{~mm}$ per $10 \mathrm{~m}$ for field $\mathrm{R} 1$ (due to less diverse shape surface). In order to proper capturing of the tussocks spatial structure a scanning was determined from different scanner positioned spots selected usually in the middle of the experimental field sides. From four up to five stations were measured per every experimental field, depends on tussocks density and height above the field bottom. Schema of an exemplary measurement field (with scanner and reference sphere positions) is shown in Figure 2.
In order to register several scans of the same field but from different spots, five calibration spheres were distributed in selected places, well visible from every scanner positioned spots. They allows automatically relation of each scan in post processing analysis. The spheres stand point was measured using GPS RTK with correction from ASG EUPOS kinematic service (http://www.asgeupos.pl). The accuracy of this method is in a range of centimeters. Then, georeference was added to each field, by calculating and referring it to spheres center point.

\section{Data post-measurement pre-processing}

Collected data from laser scanning were registered, calibrated and georeferenced, using laser scanning software - Leica Cyclone and GPS RTK measurement results. Each point cloud was isolated so that it only covers analyzed field.

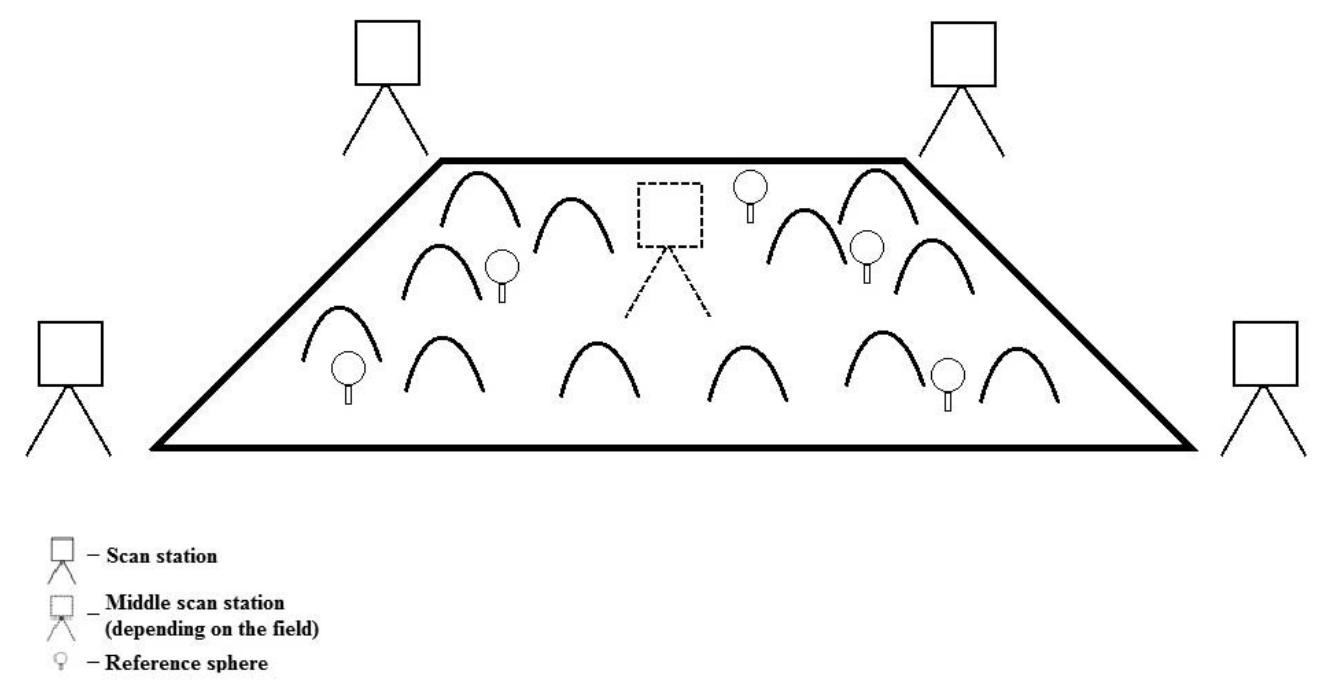

FIGURE 2. Measurement field schema 


\section{Filtration using intensity of the returning laser beam}

In order to eliminate points representing remnants of vegetation that could not be cut out manually, filtration method using classification of points by the value of the returning laser beam intensity was used. Scanners laser is sending beams in the range of infrared radiation, which can be correlated to vegetation and others objects in point cloud (Guarnieri et al., 2009). The classification was done by determining the range of returning laser beam intensity values for vegetation; as a result point cloud was classified as vegetation points and non-vegetation points. Points representing vegetation were deleted. A result of this filtration method was a point clouds with much lower noise (which was generated by a vegetation points).

\section{Process of creating a Digital Terrain Model (DTM)}

The DTM of each field was generated. For this purpose it was necessary to perform interpolation of point cloud and additional interpolation of the field ground surface, between tussocks (scanner did not register points that were in the observation shadow between tussocks). DTMs were generated using SAGA-GIS software, and resulted with a GRID with spatial resolution of $0.01 \mathrm{~m}$. The DTMs were generated with voids - lacking information due to shadow (Fig. 3).

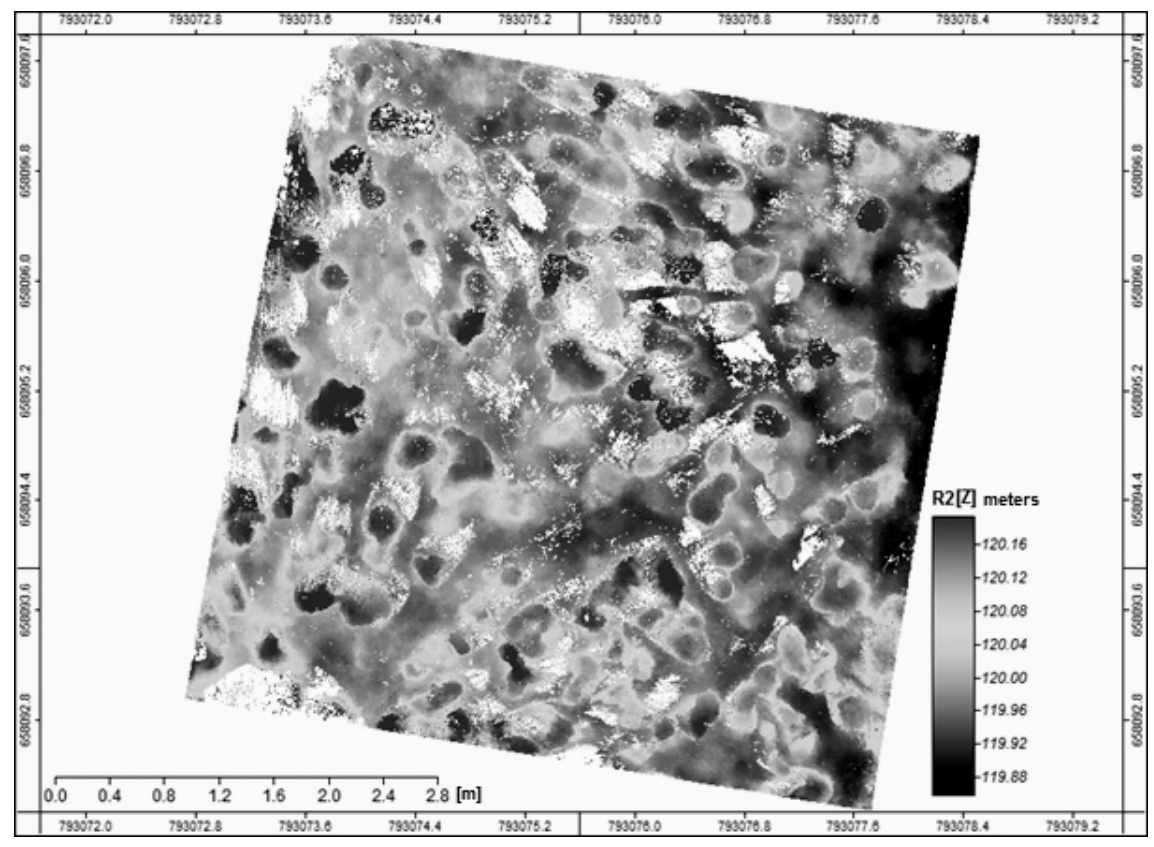

FIGURE 3. Field R2 DTM with voids between tussocks 
In order to complement it, the ground (bottom) model was determined and used to supplement lacking information of ground. The ground model was determined using ordinary kriging analysis with 40 points sampled from existing ground points in DTM regularly distributed in whole square every field. Finally the DTM was filtered using firstly the majority filter (to filter the remaining noise from vegetation) and secondly, the mean low pass filter (to refine more natural character of model). Sharma et al. (2010) used similar filtration steps in order to develop DTM vegetation removal method, from airborne LiDAR data.

\section{RESULTS AND DISCUSSION}

\section{Point cloud registration and calibration}

Laser scanner accuracy is in the range of a few millimeters. Reference spheres points were measured with accuracy of a few centimeters. Lower accuracy of reference points affects the point cloud registration, however obtained overall accuracy is sufficient for the analysis aim of this paper. Registration result in Leica Cyclone is presented by the average root mean square error (RMS), maximum root mean square error and error vector (Green, 2012). The first value shows the average error amount for all the scan stations registered in the point cloud, second the biggest error value between two scan stations. It was important to check error values, when regis- tering with GPS RTK reference points. Each reference point has its own error in GPS RTK accuracy range. So adding more points may increase the total RMS which results in lower point cloud quality. Each point cloud was registered using a set of three to four reference spheres, so it generate RMS did not exceed over GPS RTK accuracy. The average RMS for each field was $0.004 \mathrm{~m}$, while maximum RMS was $0.028 \mathrm{~m}$. As a result of registration process georeferenced and calibrated point clouds were acquired, and then were used to create DTM of an each measurement field.

\section{Digital Terrain Model quality analysis}

Despite the fact that the vegetation was removed before scanning was made, there were still some remnants that could not be removed manually. They are represented as noise on the DTM (Fig. 3). Filtrations process used in this analysis filtered those points from the model. Majority and low pass - Gaussian filters were used. Majority filter had effect on single points with large difference in values between neighbor points. Effects obtained after using of the majority filter are shown on Figure 4.

As a result of majority filter edges of objects on model have been sharpened. In order to reduce that effect a Gaussian filter was used to smooth the edges, and simulate quasi natural shape to tussocks. Effects of Gaussian filter are shown on Figure 5. 


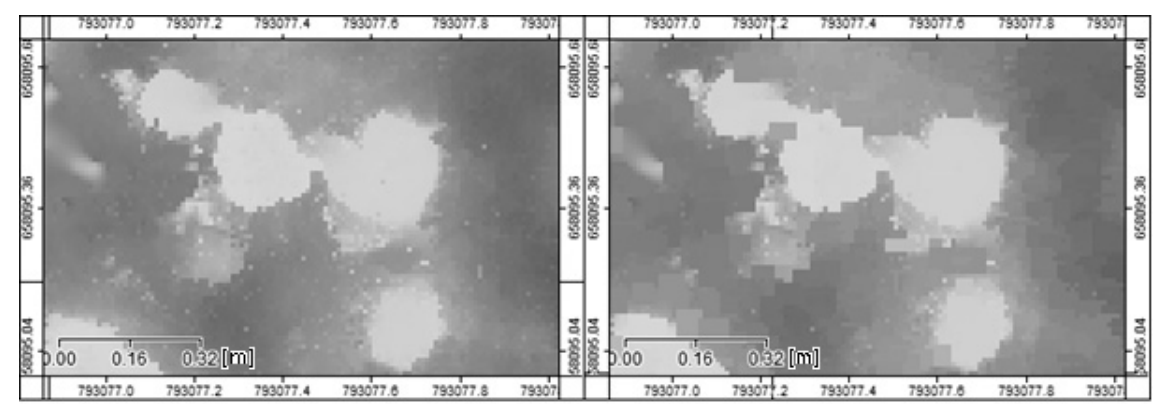

Nonfiltered

Majority filter

FIGURE 4. Impact of the majority filter on the fragment of the field R2 DTM

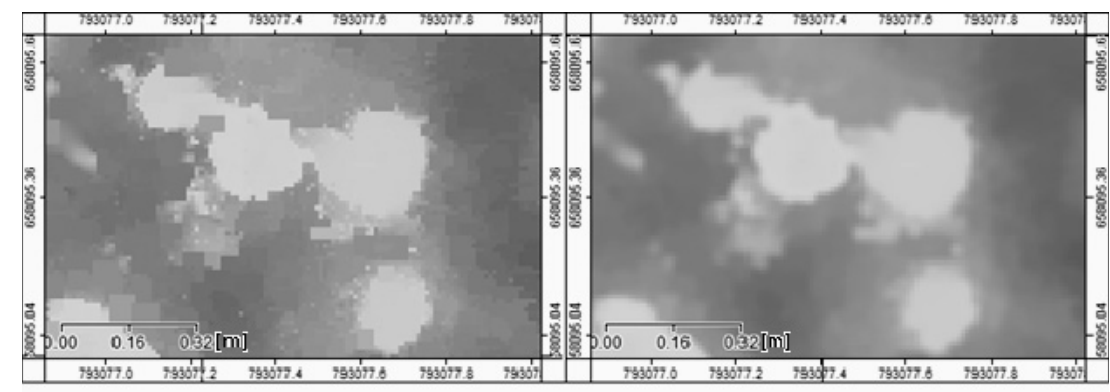

Majority filter

Mean filter

FIGURE 5. Impact of the Gaussian filter on the fragment of the field R2 DTM

By filtration methods used in this study it was possible to dispose of remaining noises made mostly by the remnants of vegetation. Big impact on DTM accuracy has the density of tussocks, their height and vegetation remnants. The higher tussocks density, the bigger probability that scanner will not register points of ground between them. That is why correct field ground interpolation is important in processing of the DTM per each square field.

\section{DTM spatial analysis}

All analysed fields were restricted to a $25 \mathrm{~m}^{2}$ area. During tussock spatial analysis the important values were tussocks mean height, overall volume and their density. Tussocks density represents how much on the $1 \mathrm{~m}^{2}$ of field is covered by the tussocks, while mean height represent average height of the tussocks (without ground) in the measured field. Tussocks are cylindrical that have more or less similar structure in nearest area. While in whole valley their structure changes due to distance to river or agriculture use (mowing). In Table 1 there is shown tussocks mean height with their volume, while Figure 6 represents their density change in relation to their height. Considering only tussocks 
mean height and volume shows that bigger mean height generates bigger volume (comparing fields R4 and R5).

TABLE 1. Tussocks height and volume values

\begin{tabular}{|c|c|c|c|}
\hline $\begin{array}{c}\text { Measu- } \\
\text { rement } \\
\text { field }\end{array}$ & $\begin{array}{c}\text { Mean } \\
\text { height } \\
{[\mathrm{m}]}\end{array}$ & $\begin{array}{c}\text { Maximum } \\
\text { height } \\
{[\mathrm{m}]}\end{array}$ & $\begin{array}{c}\text { Volume } \\
{\left[\mathrm{m}^{3}\right]}\end{array}$ \\
\hline R1 & 0.07 & 0.12 & 1.04 \\
\hline R2 & 0.21 & 0.43 & 1.08 \\
\hline R3 & 0.16 & 0.40 & 1.67 \\
\hline R4 & 0.20 & 0.47 & 1.62 \\
\hline R5 & 0.27 & 0.48 & 2.12 \\
\hline
\end{tabular}

But it also shows that field R3 with lower mean height of tussocks has bigger volume then field R4 with bigger height. While they are smaller on field R3, they are more dense. On Figure 6 it for height of $0 \mathrm{~cm}$ (tussocks density on the bottom of the field) it can be seen that they have bigger density (76.71\%) then field R4 (71.00\%). When we compare their density distribution in relation to height, it can be seen that on field R3 their density is higher. It can also be seen

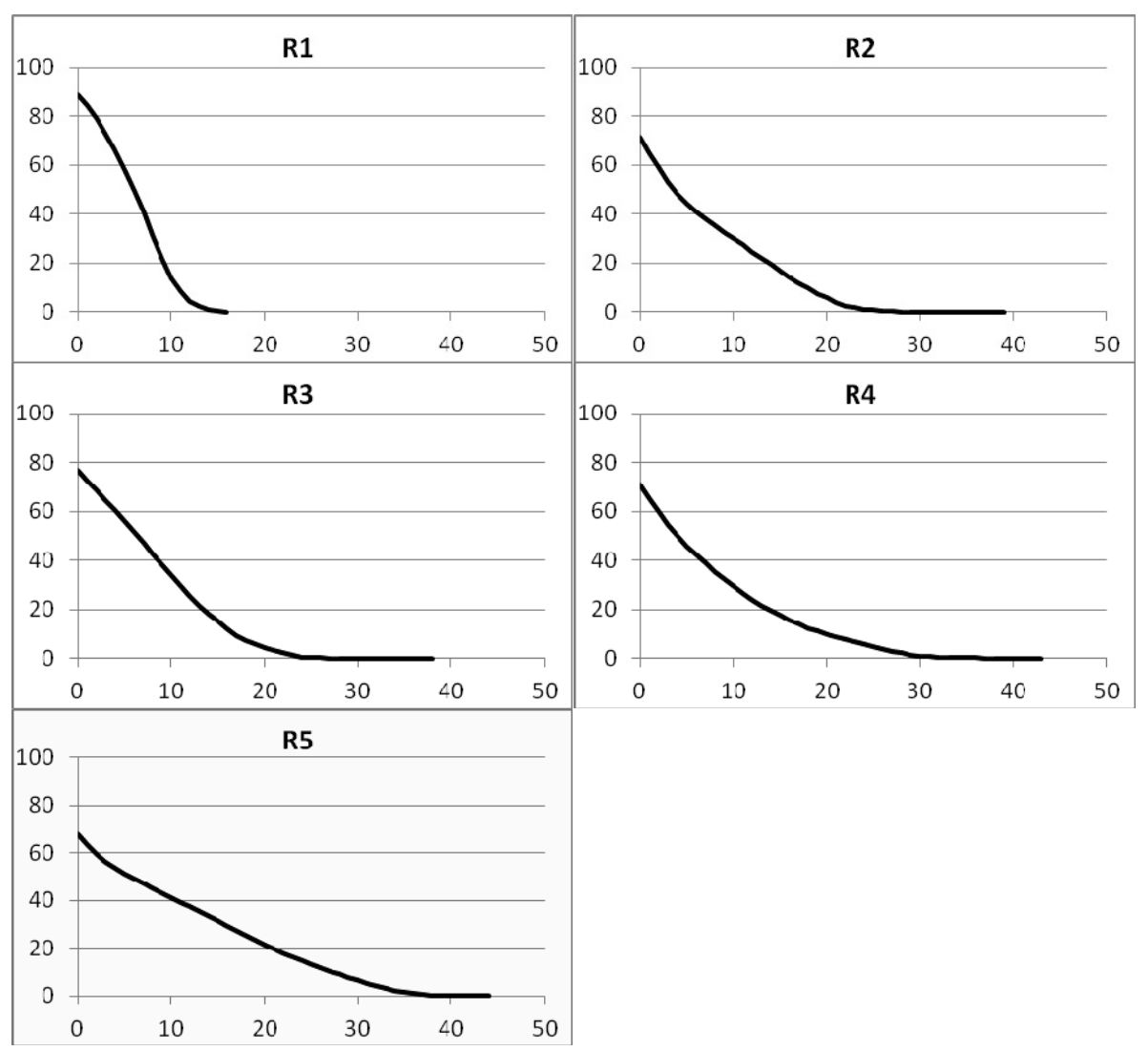

FIGURE 6. Tussocks density in relation to their height: axis $\mathrm{y}$ - density [\%], axis $\mathrm{x}$ - height of tussocks $[\mathrm{cm}]$ 
that on smaller tussocks (fields R1 and R3), their density is higher. That is why it is also important to consider tussocks density on the area. The density is represented as percent of the tussocks by the DTM area.

Results show that the bigger tussocks are and the more dense they are, the higher volume they have. The field R1 has the highest sedges density, but it tussocks are small due to fact it was mowed in recent years, and the process of tussocks formation has just begun on this area. This is important while analyzing bigger fields of sedges. This information can help determine the tussocks impact on meadows.

\section{Conclusions}

In the method proposed in this paper we generated an accurate DTM of the river valley microtopography, using integrated GIS and TLS techniques. A very important factor is a filtration process of the returning laser beam intensity from the vegetation stands. Providing trimmed tussocks was important to establish their structure, however despite the fact that the vegetation was removed manually there were still some reflected from vegetation points. That is why using this filtration method gave satisfactory results. But it could not filter all the noise, due to fact that even when specifying intensity range for vegetation, some points of ground are in that range and vice versa. When there is too big range of vegetation, we are losing ground and tussock points.
That is why it is important to determine that range correctly. High accuracy of a few millimeters offered by laser scanners is required while analyzing more technical objects and structures, than tussocks analyzed in this paper. Using GPS RTK measurements for georeferencing affected accuracy of data. The accuracy of GPS RTK measurements is in range of $5 \mathrm{~cm}$, which resulted in lower accuracy for DTM. Despite that the accuracy for these data is high enough to be considered an accurate results. Obtained data and constructed from them DTM are being considered due to their possibility to use in further hydrological analysis like water storage capabilities of river valley and in hydrodynamic models. Interpolating the point cloud into DTM was very complex. GIS methods gave proper results and resulted in popular format that is easy to analyse and interpret. Implementation of GIS analysis was important due to the fact that the attempt to link data from TLS with GIS solutions is key in future work in relating these data with other GIS data formats like DTM of the whole river valley. Grid filtration method also had their effect on model accuracy. It was important to use these filters to eliminate remnants of noise and to smooth DTM.

Results of this study enhance importance of estimation of the tussocks mean height, volume and their spatial distribution expressed also by density parameter. It could be a key in the future when considering them while construct- 
ing more complex model of a river valley. Integrating TLS data with existing DTM of the whole river valley could improve DTM (also made by use of the ALS method), what increase accuracy of the hydrological analysis. We can see also a space for fusion of the TLS data with the ALS data, which can gives a high accuracy cloud point in a specific areas, covered by dense vegetation (in contrast to the previously mentioned accuracy in the range of 0.3 to $0.5 \mathrm{~m}$ ).

\section{Acknowledgements}

Authors would like to thank Przemysław Jakowlew and Stanisław Zachara from TPI Warsaw for scanner rent and their help with scanning and exporting of scanning data.

\section{REFERENCES}

ANIBAS C., VERBEIREN B., BUIS, K., CHORMAŃSKI J., De DONCKER L., OKRUSZKO T., MEIRE P., BATELAAN O. 2012: A hierarchical approach on groundwater-surface water interaction in wetlands along the upper Biebrza River, Poland Hydrological Earth System Science, 16, 2329-2346.

BREMER M., SASS O. 2012: Combining airborne and terrestrial laser scanning for quantifying erosion and deposition by a debris flow event. Geomorphology 138, 49-60.

BUBECK A., WILKINSON M., ROBERTS G.P., COWIE P.A., MC CAFFREY K.J.W., PHILIPS R., SAMMONDS P. 2014: The tectonic geomorphology of bedrock scarps on active normal faults in the Italian Apennines mapped using combined ground penetrating radar and terrestrial laser scanning. Geomorphology. DOI: 10.1016/j.geomorph.2014.03.011.

CHORMAŃSKI J., MIROSŁAW-ŚWIĄTEK D., MICHAŁOWSKI R. 2009: A hydrodynamic model coupled with GIS for flood character- istics analysis in the Biebrza riparian wetland. Oceanological and Hydrobiological Studies 38(1), 65-73.

CHORMAŃSKI J., OKRUSZKO T., IGNAR S., BATELAAN O., REBEL K.T., WASSEN M.J. 2011a: Flood mapping with remote sensing and hydrochemistry: A new method to distinguish the origin of flood water during floods. Ecological Engineering 37(9), 1334-1349.

CHORMAŃSKI J., BEREZOWSKIT., OKRUSZKO T., IGNAR S. 2011b: Hydrography and Hydrology od the Upper Biebrza Basin. Contempoary Problems of Management and Environmental Protection 7. Issues of Landscape Conservation and Water Management in Rural Areas.

FAN L., POWRIE W., SMETHURST J., ATKINSON P.M., EINSTEIN H. 2014: The effect of short ground vegetation on terrestrial laser scans at local scale. ISPRS Journal of Photogrammetry and Remote Sensing 95, 42-52.

GREEN V. 2012. Leica Cyclone 7.1.1: Registering Scans in Cyclone. CAST Technical Publications Series. Number 7412. http://gmv.cast. uark.edu/scanning/software/leica-software/ leica-cyclone/leica-cyclone-7-1-1-registering-scans-in-cyclone-2 [Accessed: 31 December 2013, last updated: 9 May 2012].

GUARNIERI A., VETTORE A., PIROTTI F., MENENTI M., MARANI M. 2009: Retrival of small-relief marsh morphology from Terrestrail Laser Scanner, optimal spatial filtering and laser return intensity. Geomorphology 113(1-2), 12-20.

ISOK - IT System of the Country's Protection. http://www.isok.gov.pl/en [Accessed: $11 \mathrm{Au}-$ gust 2014].

JANKOWSKI W. 2003: Different proposals of flood protection in the Odra valley between Chałupki and the Nysa Łużycka, and their impact on the proposed Natura 200 sites. International conference 'Towards natural flood reduction strategies', Warsaw, 6-13 September 2003.

KALUŻA T., STRZELIŃSKI P. 2009: Remote sensing in research of high-growing plants for flow estimation in flood lands. Studia $i$ Materiały Centrum Edukacji Przyrodniczo-Leśnej 11, 2 (21). 
KOCIUBA W. 2014: Application of Terrestrial Laser Scanning in the assessment of the role of small debris flow in river sediment supply in the cold climate environment. Annales UMCS B 69, 1, 79-91.

KOCIUBA W., KUBISZ W., ZAGÓRSKI P. 2014: Use of terrestrial laser scanning (TLS) for monitoring and modelling of geomorphic processes and phenomena at small and medium spatial scale in Polar environment (Scott River - Spitsbergen). Geomorphology 212, 84-96.

KOCIUBA W., JANICKI G., RODZIK J. 2014b: $3 \mathrm{D}$ laser scanning as a new tool of assessment of the dynamics of development of forested loess gullies based on the example of Kolonia Celejów (Lublin Upland). Annales UMCS B 69, 1, 107-116.

KUHN D., PRÜFER S. 2014: Coastal cliff monitoring and analysis of mass wasting processes with the application of terrestrial laser scanning: A case study of Rügen, Germany. Geomorphology 213, 153-165.

MIROSŁAW-ŚWIĄTEK D., OKRUSZKO T., CHORMAŃSKI J. 2004: Natural floodplain storage capacity - modelling approach. Journal of Water and Land Development 8, 75-86.

MIROSŁAW-ŚWIĄTEK D., CHORMAŃSKI J. 2007: The verification of the numerical river flow model by use of Remote Sensing. In: Wetlands: Monitoring, Modelling, Management. Eds T. Okruszko, E. Maltby, J. Szatyłowicz, D. Mirosław-Świątek, W. Kotowski. Taylor \& Francis/Balkema, 173-180.

MIROSŁAW-ŚWIĄTEK D., SZPORAK S., CHORMAŃSKI J., IGNAR S. 2007: Influence of a different land use on a flood extent in the lower Biebrza valley. The Fifth International Symposium on Environmental Hydraulics (ISEH V) Tempe, Arizona, the Grand Canyon State, 4-7 December 2007, 1-7.

MIROSŁAW-ŚWIĄTEK D., SZPORAK S., CHORMAŃSKI J., OKRUSZKO T. 2008: Hydrodynamic model of the lower biebrza river flow a tool for assessing the hydrologic vulnerability of a floodplain to management practices. Ecohydrology and Hydrobiology 8(2-4), 331-337.
MOSKAL L.M., ZHENG G. 2012: Retrieving Forest Inventory Variables with Terrestrial Laser Scanning (TLS) in Urban Heterogeneous Forest. Remote Sens. 4, 1, 1-20.

OKRUSZKO T., CHORMAŃSKI J., MIROSŁAW-ŚWIĄTEK D., GREGORCZYK M. 2010: Hydrological characteristics of swamp communities, the Biebrza River (NE Poland) case study. In: Environmental Hydraulics. Eds J. Christodoulou, P. Stamou. Taylor \& Francis Group, London, 407-412.

OPDEKAMP W., TEUCHIES J., VREBOS D., CHORMAŃSKI J., SCHOELYNCK J., VAN DIGGELEN R., MEIRE P., STRUYF E. 2012: Tussocks: Biogenic Silica Hot-Spots in a Riparian Wetland. Wetlands 32, 1115-1124.

SHARMA M., PAIGE G.B., MILLER S.N. 2010: DTM Development from Ground-Based LiDAR Data: A Method to Remove Non-Surface Objects. Remote Sens. 2, 2629-2642.

WĘŻYK P., SROGA R., SZWED P., SZOSTAK M., TOMPALSKI P., KOZIOŁ K. 2009: The application of terrestrial laser scanning for determining the selected trees and forest stand parameters. Archiwum Fotogrametrii, Kartografii i Teledetekcji, 19.

Streszczenie: Naziemny skaning laserowy (TLS) jako technologia defekcji naturalnej mikrorzeźby doliny rzecznej na przykładzie górnej Biebrzy. Niniejsza praca dotyczy wykorzystania metod Naziemnego Skaningu Laserowego (z ang. TLS - Terrestial Laser Scanning) oraz analiz z wykorzystaniem Systemów Informacji Geograficznej (z ang. GIS - Geographic Information Systems) do określenia mikrorzeźby doliny rzecznej na przykładzie fragmentu doliny górnej Biebrzy. Pomiary TLS wykonano dla wybranych poletek pomiarowych zlokalizowanych w obszarze doliny, gdzie występują zbiorowiska turzyc kępowych, których systemy korzeniowe tworzą w połączeniu z namułami charakterystyczne pagórki. Przed wykonaniem skaningu części liściowe roślin zostały usunięte, aby odsłonić pagórki. W wyniku przeprowadzenia skaningu otrzymano obraz mikrorzeźby w postaci chmury punktów, który zwykle nie jest rejestrowany przez Lotniczy Skaning Laserowy (z ang. ALS - Airborne Laser Scanning) i jest główną przyczyną niedokładno- 
ści wykonywanego na jego podstawie Numerycznego Modelu Terenu (z ang. DTM - Digital Terrain Model). Na podstawie otrzymanych chmur punktów wygenerowano NMT dla każdego z pól pomiarowych. Otrzymany NMT został poddany filtracji różnymi metodami w celu zmniejszenia szumu oraz wypełnienia pustych miejsc modelu powstałych na skutek blokowania wiązki lasera przez kępy roślinności. Pozwoliło to określić strukturę przestrzenna każdego analizowanego poletka.
Stowa kluczowe: naziemny skaning laserowy, dorzecze górnej Biebrzy, Systemy Informacji Geograficznej, mikrorzeźba doliny rzecznej

MS. received August 2014

Authors' address:

Marcin Brach, Jarosław Chormański

Katedra Inżynierii Wodnej SGGW

ul. Nowoursynowska 166, 02-787 Warszawa

Poland

e-mail: m.brach@levis.sggw.pl 